\title{
PEMURNIAN DAN KARAKTERISASI LEKTIN DARI ALGA LAUT Eucheuma cotonii
}

\section{(Purification and Characterization of A Lectin from the Marine Red Alga Eucheuma cotonii)}

\author{
L.D. Rawung ${ }^{1 *}$, R.E.P. Mangindaan ${ }^{2}$, J. Posangi ${ }^{3}$ \\ ${ }^{1}$ Program studi Biologi Fakultas Matematika dan Ilmu Pengetahuan Alam, Universitas Negeri \\ Manado, \\ 2 Program Studi Ilmu Kelautan Fakultas Perikanan dan Ilmu Kelautan, Universitas Sam \\ Ratulangi Manado \\ ${ }^{3}$ Fakultas Kedokteran, Universitas Sam Ratulangi Manado \\ e-mail: livana83@yahoo.com
}

Lectins are proteins that binding mono-oligosaccharides specifically and reversibly but are devoid of catalytic activity (i.e. are not enzymes) and, in contrast to antibodies, are not products of an immune response. Lectin can agglutinate any kinds of cells such as, lymphocyte, sperm, bacteria and fungi. With this features, lectin can play a role in preventing of HIV and AIDS infection and surviving to virus and infection of bacteria and also preventing fertilization. In spite of the progress made in the biochemical characterization of marine algal lectin, additional information is needed for a more comprehensive understanding of their properties, structure and possible biological functions. This research use Eucheuma cotonii as lectin source. Purification of lectin was conducted by using a series method; extraction, chromatography column and SDS-PAGE respectively. Determination of lectin characteristic was conducted by examination to erythrocytes and sugars to determine the hemagglutinating activity and specific sugar. From yield of extraction lectin crude extract was found as much as $1,86 \%$ from their dry weight. After pass chromatography column, from 25 tubes that was obtained just 5 tubes that contain lectin. From SDS-PAGE was obtained pure lectin with molecule weight about $11,7 \mathrm{kD}$. The smallest concentration of lectin that still has hemagglutinating activity is 2,75 $\mu \mathrm{g} \cdot \mathrm{mL}^{-1}$. Hemagglutinating activity by this lectin can be inhibited by L-Rhamnose and Maltose sugars.

Keywords: Lectin, marine algae, Eucheuma cotonii

Lektin adalah protein yang mengikat monosakarida dan oligosakarida secara spesifik tetapi tanpa aktivitas katalisis (yaitu bukan enzim) dan, berbeda dengan antitibody yaitu bukanlah produk dari suatu respon sistim pertahanan tubuh. Lektin dapat mengagglutinasi berbagai macam sel seperti limfosit, sperma, bakteri dan jamur. Dengan sifat-sifatnya ini, lektin dapat berperan dalam pencegahan infeksi HIV dan AIDS dan pertahanan terhadap virus dan infeksi dari bakteri dan juga pencegahan terjadinya pembuahan. Walaupun peningkatan telah dibuat melalui karakterisasi biokimia dari lektin alga laut ini, informasi tambahan diperlukan untuk pengertian yang lebih komprehensif tentang sifat-sifat, struktur bahkan fungsi biologis mereka. Penelitian ini menggunakan alga merah laut Eucheuma cotonii sebagai sumber lektin. Pemurnian lektin menggunakan serangkaian metode yang dimulai dari ekstraksi, kolom kromatografi dan diakhiri dengan SDS-PAGE. Penentuan karakteristiknya dilakukan melalui pengujian terhadap eritrosit dan beberapa jenis gula untuk menentukan aktivitas hemaglutinasi dan jenis gula spesifik. Dari hasil Ekstraksi ekstrak kasar lektin diperoleh sebanyak 1.86\% dari berat keringnya. Setelah melewati kolom kromatografi dari 25 tabung yang dihasilkan hanya diperoleh 5 tabung yang memiliki kandungan lektin. Melalui SDS-PAGE diperoleh lektin murni dengan berat molekul $11,7 \mathrm{kD}$. Konsentrasi terkecil lektin yang masih memiliki aktivitas hemagglutinasi adalah 2,75 $\mu \mathrm{g} \cdot \mathrm{mL}^{-1}$. Aktivitas hemaglutinasi lektin ini dapat dihambat oleh gula L-Rhamnose dan Maltose.

Kata kunci: Lektin, alga laut, Eucheuma cotonii 


\section{PENDAHULUAN}

Lektin (bahasa Latin, leger: menyeleksi atau memilih) merupakan protein yang dapat mengikat monosakarida dan oligosakarida secara spesifik namun bukan merupakan enzim dan berbeda dengan antibodi dimana lektin tidak dapat menghasilkan respon imun (Sharon and Lis, 1989). Menurut Cummings (1997) antibodi dan protein dengan aktivitas enzimatik yang dihubungkan dengan karbohidrat tidaklah dapat dikelompokkan sebagai lektin.

Lektin terdistribusi sangat luas di alam dan bisa ditemukan pada hampir semua makhluk hidup termasuk tumbuhan, alga, jamur, hewan (vertebrata dan invertebrata), mikroorganisme dan virus. Lektin telah banyak diisolasi kebanyakan dari tumbuhan darat. Walaupun demikian peranan mereka dalam makhluk hidup masih sukar dipahami. Lektin yang berasal dari hewan dan tumbuhan telah banyak dieksploitasi sebagai alat biokimia dalam penelitian bioteknologi dan biomedikal seperti imunologi, biologi sel, struktur membran, penelitian kanker dan rekayasa genetik (Van Driessche et al., 1996; Gabius and Gabius 1997; Lis and Sharon 1998).

Boyd et al. (1996) pertama kali melaporkan keberadaan lektin dari alga laut. Walaupun demikian informasi tentang pemurnian dan karakterisasi lektin dari alga masihlah terbatas dibandingkan dengan lektin yang berasal dari tumbuhan tingkat tinggi dan invertebrate (Rogers and Hori, 1993). Karakterisasi lektin yang berasal dari alga berbeda dengan yang berasal dari tumbuhan tingkat tinggi. Pada umumnya lektin dari alga memiliki berat molekul yang lebih kecil dari kebanyakan lektin yang dari tumbuhan tingkat tinggi (Roger and Hori, 1993).

Kebanyakan lektin telah diisolasi dari alga merah seperti Eucheuma gelatinae, Gracillaria verucosa, Jania sp, Sargssum sp and Turbinaria ornata (Kumajas, 1994),
Bryothamnion seaforthii and $B$. triquetrum (Ainouz et al., 1995), Enantiocladia duperreyi (Benevides et al., 1998) and Pterocladiella capillacea (Oliveira et al., 2002),.

\section{METODE PENELITIAN}

\section{Pengambilan Sampel}

Sampel yang diambil adalah jenis alga merah yaitu Eucheuma cotonii dari perairan Karor, Lembean Timur. Sebelum digunakan alga dicuci dengan air tawar untuk menghilangkan garam dan organisme yang menempel. Selanjutnya alga dipotong-potong kecil dan dikeringkan menggunakan ice dryer kemudian digiling menjadi bubuk.

\section{Ekstraksi}

Ekstraksi lektin dilakukan (Bollag and Edelstain, 1991) yang umum dilakukan dengan beberapa modifikasi. Tepung alga laut sebanyak $50 \mathrm{gr}$ ditambahkan $500 \mathrm{ml}$ fosfat buffer $(\mathrm{M} / 15, \mathrm{pH} 7)$, diaduk dengan pengaduk listrik selama 24 jam, pada temperatur $5^{\circ} \mathrm{C}$. Setelah pengadukan, campuran disaring dengan saringan biasa untuk mengeluarkan debris kasar. Filtrat yang diperoleh disentrifus pada kecepatan 3200 rpm selama 10 menit atau sampai sisa-sisa debris mengendap. Supernatan hasil sentrifus ditambahi dengan amonium sulfat $\left(\mathrm{NH}_{4}\right)_{2} \mathrm{SO}_{4}$ sedikit demi sedikit sampai larutan menjadi jenuh. Dengan proses salting out ini, protein yang terlarut menjadi bentuk yang tersuspensi. Setelah itu disentrifus pada kecepatan 3200 rpm selama 15 menit. Presipitatnya dimasukkan kedalam kantong dialisis dan didialisis pada PBS (Phosphate Buffer yang mengandung $0,85 \% \mathrm{NaCl}) \mathrm{pH} 7$, sambil diaduk dengan magnetik stirrer pada temperatur $5^{\circ} \mathrm{C}$. Dialisis protein pada membran selulosa berlangsung selama 12 jam dengan pergantian PBS yang dilakukan pada jam ke-3 dan jam ke-4. 
Ekstrak lektin yang diperoleh kemudian ditambah dengan Natriumazid $\left(\mathrm{NaN}_{3}\right)$ $0,02 \%$.

\section{Penentuan Aktivitas Lektin}

Ekstrak kasar lektin dilarutkan kembali dalam salin 0,85 \% dengan kosentrasi awal $10 \mathrm{mg} / \mathrm{ml}$, setelah itu di saring dengan kertas saring $0,2 \mu \mathrm{m}$ untuk mengeluarkan debris. Sebanyak $100 \mu \mathrm{l}$ salin 0,85 \% dimasukkan ke tiap cekungan pada microtiter plate. Ekstrak kasar lektin sebanyak $100 \mu \mathrm{l}$ ditambahkan pada cekungan no 1 dan diaduk dengan mikropipet, kemudian $100 \mu \mathrm{l}$ campuran tersebut dipindahkan ke cekungan ke-2 dan diaduk, demikian dilakukan seterusnya sampai cekungan ke-7 dan $100 \mu \mathrm{l}$ dari cekungan ke-7 akan dibuang, sehingga terbentuk suatu seri pengenceran 2 kali. Pada cekungan ke-8 tidak ditambahi ekstrak lektin sehingga berlaku sebagai kontrol. Kedalam tiap cekungan ditambahkan $100 \mu \mathrm{l}$ suspensi eritrosit. Setelah pengadukan perlahan, keseluruhan plate ditutup dengan palstik tipis (cling warp) untuk mencegah penguapan. Selanjutnya diinkubasi salama dua jam pada suhu ruangan.

Titer aglutinasi ditentukan pada titik pengenceran tertinggi yang memberikan aglutinasi positif. Misalnya pada pengeceran $2^{-3}$ masih menunjukkan aglutinasi yang positif, maka nilai aktivitas lektin tersebut adalah 3. Pengamatan aglutinasi dilakukan secara makroskopis dan mikroskopis (menggunakan mikroskop).

\section{Penentuan Gula Spesifik}

Untuk penetuan Gula Spesifik pengujian dilakukan pada microtiter plate dan pengamatan uji hambat dilakukan secara makroskopis. Jenisjenis gula yang digunakan yaitu, $D(-)-$ Arabinose, D(+)-Xylose, D(+)-Glucose, $\mathrm{D}(+)$-Galactose, Manitol, L-Rhamnose, Inositol, $\quad \mathrm{D}(+)$-Mannose, $\mathrm{D}(+)$ Glucosamine, Sodium glucuronat, Nacetyl-D-glucosamine, Maltose,
Lactose, Saccharose dan Raffinose. Polisakarida yang digunakan yaitu Arabic gum dan Starch potato. Setiap jenis gula dilarutkan dalam salin dengan kosentrasi $200 \mathrm{mM}$. Dengan multimikropipet, $100 \quad \mu \mathrm{l}$ salin dimasukkan kecekungan nomor 1 sampai 6. Selanjutnya dengan mikropipet $100 \mu \mathrm{l}$ larutan gula (200 $\mathrm{mM}$ ) ditambahkan pada cekungan ke-1 dan diaduk. Sebanyak $100 \mu \mathrm{l}$ dari campuran tersebut dipindahkan pada cekungan ke-2 dan diaduk. Demikian seterusnya sampai pada cekungan ke5 , sehingga terbentuk suatu seri pengenceran 2 kali dari larutan gula. Cekungan ke-6 tidak ditambahkan larutan gula, sehingga berlaku sebagai kontrol. Pada tiap cekungan ditambahi ekstrak lektin dengan kosentrasi titer tertinggi yang masih menunjukkan aktivitas aglutinasi.

Uji hambat gula ditentukan setelah inkubasi selama 60 menit pada suhu ruangan dan diuji terhadap eritrosit manusia. Tiap cekungan diisi suspensi eritrosit $(0.5 \%)$ sebanyak $100 \mu \mathrm{l}$. Gula spesifik ditunjukkan ketika tidak terjadi proses aglutinasi terhadap sel darah merah.

\section{Isolasi Lektin menggunakan Metode SDS-PAGE dan Penentuan Berat Molekul}

Lektin di isolasi dengan menggunakan metode SDS-PAGE (Bollag dan Edelstein, 1991). Plate dari gel elektroforesis kemudian disuntikkan larutan pemisah (separating gel) kemudian setelah terjadi polymerasi disuntikan stacking gel. Sebelum stacking gel terpolimerasi maka haruslah disisipkan sisir pembentuk sumur yang nantinya akan digunakan untuk memasukkan sampel lektin. Sebelum sampel dimasukkan ke dalam sumur, sampel $(20 \mu \mathrm{ll})$ dicampur dengan buffer SDS $(5 \mu \mathrm{l})$ kemudian dipanaskan pada suhu $100^{\circ} \mathrm{C}$ selama 2-5 menit. Selanjutnya sampel $(25 \mu \mathrm{l})$ dan protein marker $(5 \mu \mathrm{l})$ dimasukkan 
ke dalam sumur. Plate kaca tersebut kemudian dimasukkan ke dalam alat elektroforesis selama 2 jam pada 50 volt dengan kecepatan arus $25 \mathrm{~mA}$. Selanjutnya kemudian gel direndam kedalam commasie blue dan kemudian dicuci selama 60 menit dengan larutan pencuci dengan menggunakan shaker. Setelah dicuci maka akan kelihatan pita-pita dari protein marker dan dari lektin sehingga kemudian akan dapat ditentukan berat molekul dari lektin tersebut. Standard protein yang digunakan adalah; Phosporylase b (MW $94 \mathrm{kDa}$ ), Albumin (MW $67 \mathrm{kDa}$ ), Ovalbumin (MW 43 kDa), Carbonic anhydrase (MW $30 \mathrm{kDa}$ ), Trypsin inhibitor (MW 20,1 kDa) and $\alpha$ Lactalbumin (MW 14,4 kDa).

\section{HASIL DAN PEMBAHASAN}

\section{Ekstrasi Lektin dari Alga laut E.cotonii}

Tepung alga laut Eucheuma cotonii (gambar 1) sebanyak 50 gram menghailkan filtrat sebanyak $250 \mathrm{ml}$. Selanjutnya filtrat disalting out dan disentrifus, presipitat yang diperoleh dimasukkan ke dalam membran dialisis dan menghasilkan cairan ekstrak kasar lektin sebanyak $24.5 \mathrm{ml}$. Melalui pengeringan beku diperoleh $0.93 \mathrm{gr}$ ekstrak kasar atau $1.86 \%$ dari berat kering awal.

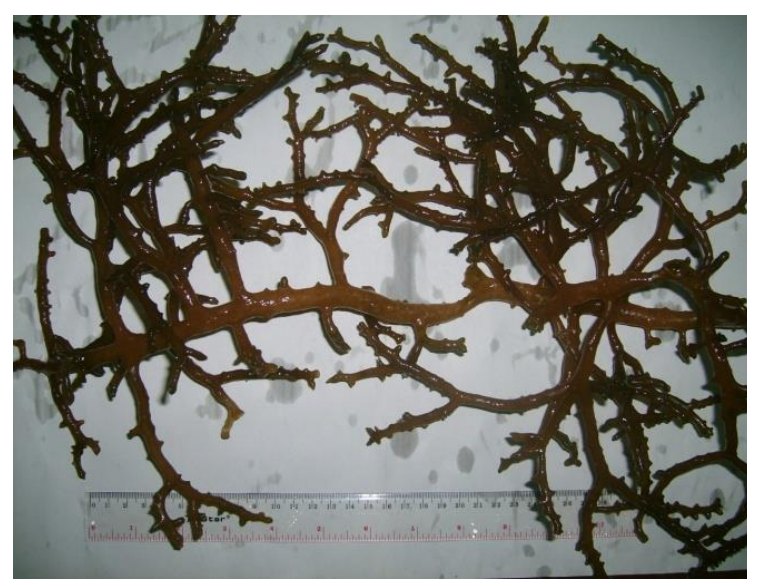

Gambar 1. Eucheuma cotonii.

\section{Aktivitas Lektin}

Hasil observasi pada mikrotiter ditunjukkan pada Gambar 2.

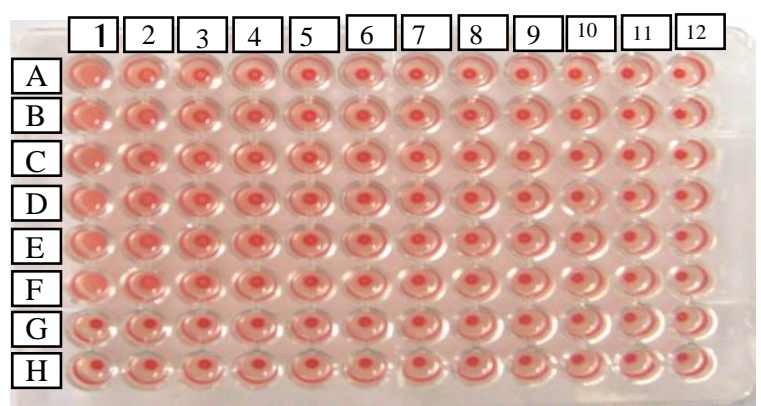

Gambar 2. Pengujian aktivitas lektin pada mikrotiterplate Baris A adalah lektin, B-F merupakan pengulangan. Baris G-H tanpa lektin. Column 1-12 merupakan rangkaian pengenceran dua kali

Pada Gambar 2 nampak bahwa sumur A sampai $F$ tidak memiliki perbedaan. Pada pengenceran $2^{-1}$ sampai $2^{-4}$ terjadi agglutinasi. Sementara pada $2^{-5}$ sampai $2^{-8}$ tidak terjadi aglutinasi. Sumur $\mathrm{G}$ sampai $\mathrm{H}$ merupakan kontrol negatif yang tidak menunjukkan aglutinasi. Secara makroskopik sangat sulit ditentukan pengenceran tertinggi yang masih tetap menunjukkan aktivitas agglutinasi. Oleh karena itu harus dilakukan pengamatan secara mikroskopik.

Pengamatan

secara mikroskopik dapat dilihat pada gambar 3 (eritrosit yang diaglutinasi) dan gambar 4(eritrosit yang tidak teraglutinasi). Pada gambar 3 nampak bahwa eritrosit saling berikatan satu dengan lainnya. Sementara pada gambar 4 sebaliknya tidak terjadi pengikatan antar sesama eritrosit.

Pengamatan

secara makroskopik menunjukkan bahwa sampai pengenceran $2^{-4}$ pada mikrotiterplate tetap menunjukkan aktivitas aglutinasi. Sementara pengamatan secara maikroskopik menunjukkan bahwa pada pengenceran ini terkadang aktivitas aglutinasinya dapat bernilai positif maupun negatif. Hal ini dikarenakan konsentrasi lektin sangatlah kecil atau 


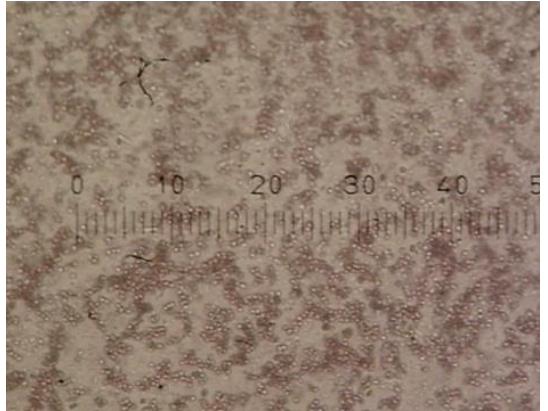

Gambar 3. Positif hemaglutinasi.Eritrosit diaglutinasi oleh lektin $(100 \mathrm{x})$.

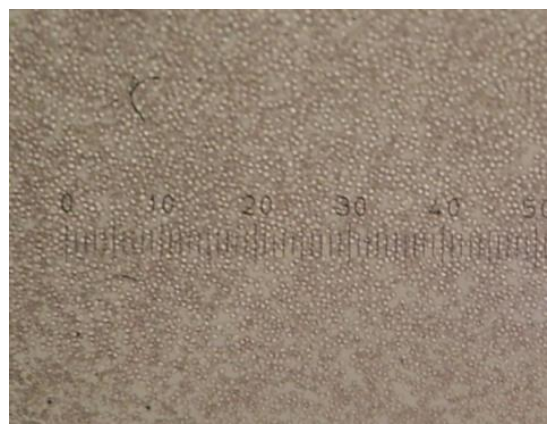

Gambar 4. Negatif hemaglutinasi. Eritrosit tanpa lektin sehingga tidak terjadi aglutinasi $(100 \mathrm{x})$

pada titik kritis. Sehingga konsentrasi terkecil yang baik dari lektin yang masih memiliki aktivitas aglutinasi diperoleh pada pengenceran titer ke 3 atau $2^{-3}$ atau konsentrasi lektin pada 2.75 $\mu \mathrm{g} \cdot \mathrm{mL}^{-1}$

\section{Penentuan Gula Spesifik}

Pada Tabel 1 nampak 17 jenis gula yang digunakan untuk menentukan aktivitas penghambatan hemaglutinasi. Apabila lektin tersebut diberikan larutan gula yang spesifik terhadap sisi pengikat gulanya, maka gula spesifik tersebut akan berikatan dengan lektin. Ketika kemudian ditambahkan dengan eritrosit yang sebelumnya dapat diikat oleh lektin maka selanjutnya tidak akan terjadi pengikatan atau hemaglutinasi. Hal tersebut dikarenakan sisi pengikat gula lektin sudah terlebih dahulu berikatan dengan gula yang ada dalam larutan sehingga tidak memungkinkan untuk mengikat gula yang ada pada membran

eritrosit sehingga tidak terjadi proses hemaglutinasi.

Hasil penghambatan hemaglutinasi oleh lektin dengan penambahan gula sederhana dan beberapa polisakarida (table 1) menunjukkan penghambatan oleh gula sederhana (Maltose, dan L-Rhamnose) dan sebaliknya oleh polisakarida. Hal ini nampak berbeda dengan kebanyakan lektin dari alga yang aktivitas hemaglutinasinya dihambat oleh polisakarida (Rogers et al., 1990, Rogers and Hori 1993).

Hemaglutinasi oleh lektin dihambat oleh penambahan Maltose sampai pada konsentrasi $50 \mathrm{mM}$ dan LRhamnose sampai pada konsentrasi $12.5 \mathrm{mM}$.

Tabel 1. Penghambatan aktivitas hemaglutinasi oleh lektin Eucheuma cotonii. $\mathrm{NI}=$ tidak terjadi penghambatan hemaglutinasi pada konsentrasi $100 \mathrm{mM}$.

\begin{tabular}{lc}
\hline \multicolumn{1}{c}{ Gula } & $\begin{array}{c}\text { Konsentrasi } \\
\text { penghambatan } \\
\text { terkecil }\end{array}$ \\
\hline $\mathrm{D}(+)$-Galactose & $\mathrm{NI}$ \\
$\mathrm{D}(+)$-Mannose & $\mathrm{NI}$ \\
Manitol & $\mathrm{NI}$ \\
Saccharose & $50 \mathrm{mM}^{*}$ \\
Maltose & $\mathrm{NI}$ \\
$\mathrm{N}$-acetyl-D- & $\mathrm{NI}$ \\
glucosamine & $\mathrm{NI}$ \\
Lactose Monohydrate & $12.5 \mathrm{mM}^{*}$ \\
D(+)-Glucose & $\mathrm{NI}$ \\
L-Rhamnose & $\mathrm{NI}$ \\
D(-)-Arabinose & $\mathrm{NI}$ \\
D(+)Glucosamine & $\mathrm{NI}$ \\
Sodium glucuronat & $\mathrm{NI}$ \\
Raffinose & $\mathrm{NI}$ \\
Inositol & $\mathrm{NI}$ \\
D $(+)-$ Xylose & $\mathrm{NI}$ \\
Strach potato & \\
Arabic gum & \\
${ }^{*}: 2.75 \mu$ g.mL ${ }^{-1}$ of lectin concentration. &
\end{tabular}


Hal yang sama juga ditunjukkan oleh lektin dari alga merah Griffithsia sp (Mori et all., 2004) and Vidalia obtusiloba C. Agardh (Melo et al., 2004) dimana penghambatan hemaglutinasi disebabkan oleh gula sederhana.

\section{Isolasi lektin dengan menggunakan SDS-PAGE}

Analisis berat molekul lektin dari alga laut Euceuma cotonii dengan SDS-PAGE menggunakan hasil kromatografi tabung kelima sampai kesembilan. Hasil pewarnaan menunjukkan bahwa terdapat pita tunggal dengan berat molekul lektin yaitu 11.668 Dalton $\approx 11.7 \mathrm{kD}$ (gambar $5)$. Hal ini sesuai dengan Rogers dan Hori (1993), dimana umumnya lektin yang berasal dari alga memiliki berat molekul yang lebih rendah dibandingkan dengan lektin tanaman tingkat tinggi seperti Bryothamnion seaforthii (Turner) Kutzing dengan berat molekul $3.5 \mathrm{kD}$ (Ainouz et al., 1995) dan B. seaforthii (Gmelin) Home dengan berat molekul $4.5 \mathrm{kD}$ (Calvete et al,. 2000). Oleh karena dari pewarnaan hanya nampak satu pita maka dapat disimpulkan bahwa lektin dari alga laut $E$. cotonii merupakan protein monomerik yang terdiri dari satu sub-unit.

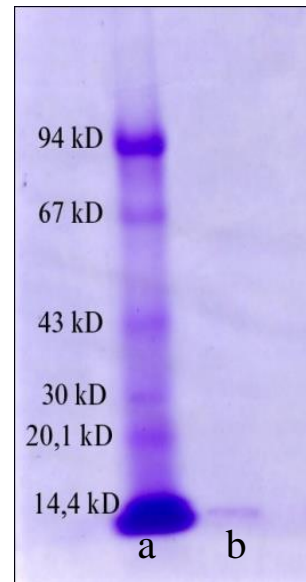

Gambar 5. Isolasi lektin dengan metode SDS-PAGE dengan menggunakan pewarnaan Coomassie Briliant Blue R 250.(a) Protein standar, Phosphorylase b, 94 kD; Albumin, 67 kD; Ovalbumin, $43 \mathrm{kD}$; Carbonic anhydrase, $30 \mathrm{kD}$; Trypsin, $20.1 \mathrm{kD}$; $\alpha$-Lactalbumin, 14.4 kD. (b) Lektin murni

Pewarnaan Coomassie Briliant Blue R-250 yang digunakan memiliki tingkat sensitivitas sekitar $0,1 \mu \mathrm{g}-1 \mu \mathrm{g}$ protein per pita, sehingga mungkin tidak dapat mendeteksi protein lektinyang memiliki konsentrasi yang lebih rendah dari kisaran tersebut. Hal ini dapat diatasi dengan menggunakan pewarnaan seperti silver (sensitivitas 10 - 100 ng protein per pita) dan tembaga (Deutcher, 1990). Berat molekul dari suatu senyawa dapat menjadi kriteria dalam melakukan analisis senyawa tersebut. Komposisi dan analisis rantai asam amino dapat dilakukan sampai pada tingkat seluler, sehingga memungkinkan untuk dapat memproduksi lektin tersebut dengan menggunakan rekayasa genetik.

\section{KESIMPULAN}

1. Pemurnian lektin dari alga laut Eucheuma cotonii menggunakan metode SDS-PAGE menunjukkan pita tunggal dengan berat molekul $\approx$ $11.7 \mathrm{kD}$.

2. Maltose dan L-Rhamnose merupakan gula spesifik terhadap sisi pengikat gula lektin $E$. cotonii.

\section{DAFTAR PUSTAKA}

Ainouz, I.L.,Sampaio, A.H., Freitas, A.L.P., Benevides, N.M.B., Mapurunga, $\quad$ S. 1995. Comparative study on haemagglutinins from the red algae Bryothamnion seaforthii and Bryothamnion triquetrum. Revista Brasileira de Fisiologia egetal 7:15-19.

Benevides, N.M.B., Holanda, M.L., Mel, F.R., Freitas, A.L.P., Sampaio, A.H. 1998. Purification and partial characterization of the lectin from the marine red algal 
Enantiocladia duperreyi (C. Agardh) Falkenberg. Botanica Marina 41:521-525.

Bollag, D.M., Edelstein, S.J. 1991. Protein Methods. Wiley-Liss. New York. p 230.

Boyd, W.C., Almodovar, L.R., Boyd, L.G. 1966. Agglutinin in marine algae for human erythrocytes. Transfusion 6:82-83.

Calvete, J.J., Costa, F.H.F., SakerSampaio, S., Murciano, M.P.M., Nagano, C.S., Cavada, B.S., Grangeiro, T.B., Ramos, M.V., Bloch, Jr., Silveira, S.B., Freitas B.P., Sampaio, A.H. 2000. The Amino Acid Sequence of the Agglutination Isolated from the Red Marine Algae Bryothamnion triquetrum defines a novel lectin structure. Cellular and Molecular Life Science 57:343-350.

Cummings, R.D. 1997. Lectins as tools for glycoconjugate purification and characterization. In Glyco-science, status and perspectives. (H.J. Gabius and S. Gabius, eds.) Champman and Hall $\mathrm{GmbH}$, Weinheim, 191$199 \mathrm{pp}$.

Deutscher, M.P. 1990. Protein Purification. Academic Press, Inc. California. p894.

Gabius, H.J., Gabius,S. 1997. Glycoscience: status and perspectives, Chapman and Hall, Weinheim.

Kumajas, J. 1994. Isolasi Agglutinin pada Beberapa Jenis Rumput Laut. Skripsi. Fakultas Perikanan dan IImu Kelautan UNSRAT. 25 hal.

Kumajas, J. 1999. Karakterisasi Aglutinin dari Beberapa Jenis
Alga Laut. TESIS. Pascasarjana UNSRAT. 25 hal.

Lis, H., Sharon, N. 1998. Lectins : carbohydrate specific proteins that mediated cellular recognition. Chemical Reviews 98:637-674

Melo, F.R., Benevides, N.M.B., Pereira, M.G. Holanda, M.L., Mendes, F.N.P., Oliveira, S.R.M., Freitas, A.L.P., Silva, L.M.C.M. 2004. Purification and Partial Characterisation of $A$ Lectin from The Red Marine Alga Vidalia obtusiloba C Agaradh. Revista Brasil.Bot., Vol 27, n.2, 263-269 pp.

Mori, T., B.R.O'keefe, R.C. Sowcler, S. Bringans, R. Gardella, S. Berg, P. Cochran, J.A. Turpin, R.W. Buckheit, J.B. McMahon and M.R. Boyd. 2004. Isolation and Characterisation of Griffithsin, A Novel HIV-Inactivating Protein, From The Red Alga Griffithsia sp. Journal Biol.Chem.

Oliveira, S.R.M., A.E. Nascimento, M.E.P. Lima, Y.F.M.M. Leite., Benevides, N.M.B. 2002. Purification and Characterisation of A Lectin From The Red Marine Alga Pterocladiella capillacea (S.G. Gmel) Santel and Holmmers. Revista Brasil. Bot., Vol. 25, n.4, 397-403 pp.

Rogers, D.J., Fish, B., Barwell, C.J. 1990. Isolation and Properties of Lectin from Two Red Marine Algae : Plumaria elegans and Ptilota serrata. In Lectin : Biology, Biochemistry, Chemical Biochemistry. (T.C. BogHansen \& D.L.J. Freed,eds) Sigma Chemical Company, St. Louis, .7, 49-52 pp. 
Rogers, D.J., Hori, K. 1993. Marine algal lectins: new developments. Hydrobiologia 260/261:589-593.

Sharon, N., Lis, H. 1972. Lectins : cellaglutinatinating and sugarspecific proteins. Science 177:949-959.

Van Driessche, E., Rouge, P. Beeckmans, S., Boghansen, T.C.. 1996. Lectins - Biology, Biochemistry, Clinical Biochemistry, v. 11, Textop, Denmark. 